\title{
References
}

1. Ianush O. Desiat navychok, shcho vriatuiut karieru v 2020-mu / O. Yanush [Elektronnyi resurs]. - Rezhym dostupu : https://studway.com.ua/10-navichok/

2. Klasyfikatora profesii DK 003:2010 (zatverdzhenyi Nakazom Derzhspozhyvstandartu Ukrainy vid 28.07.2010 № 327) [Elektronnyi resurs]. - Rezhym dostupu : http://www.ukrstat.gov.ua/klasf/nac_kls/op_dk003_2016.htm

3. Romanova E. S. 99 populjarnyh professij. Psihologicheskij analiz i professiogrammy / E. S. Romanova. - 2-e izd. - SPb. : Piter, 2008. - 464 s.

4. Semenjuk Je. P. Informatizacija obshhestva, kul'tura, lichnost' / Je. P. Semenjuk // Nauchnotehnicheskaja informacija. Serija 1. - 1993. - № 1. - S. 1-3.

5. Talizina N. F. Upravlinnja procesom zasvoennja znan' / N. F. Talizina. - M. : MDU, 1975. - 343

S.

6. Janush O. Desjat' navichok, shho vrjatujut' kar'єru v 2020-mu [Elektronnij resurs] / O. Janush. Rezhim dostupu : https://studway.com.ua/10-navichok/

V. V. Kyrychenko MODEL OF PROFESSIONAL COMPETENCIES OF THE STATE PROFESSIONAL SERVICE

In modern society there is a need for the development of a high level of information culture of the individual. The purpose of the article is development invariant model of professional competence of a civil servant and to describe the significance of information culture in its structure. It was implemented within the framework of the project Institute for Economics and Forecasting of the National Academy of Sciences of Ukraine "Assessment of the market of managerial public services and functional and competency of the civil service and civil servants in Ukraine».

In the analysis of the current regulatory framework governing the activities of public servants in Ukraine and the European public administration experience, we have identified the following invariant functions and public service and the competence of public servants in Ukraine: Making effective decisions, Ability to work with information, Ability to manage effectively, Leadership (public activity), Stress resistance, Ability to use ICT in professional activities, Ability to learn and develop new knowledge and experience, Ability to communicate and interact, Critical thinking, Change Management and Project Activity, Ability to achieve the set goals, Management of finance and other material, intellectual (spiritual) resources.

As a result of the study, we determined that information culture is part of the professional competence of professions that are related to social communication and interaction with information systems.

Key words: professional activity, public service, invariants of professional activity, competence, information culture.

УДК 159.922.6

Н.В.КОРЧАКОВА

DOI: https://doi.org/10.35619/prap_rv.vi12.58

\section{ПСИХОЛОГІЧНІ МЕХАНІЗМИ ВІКОВОЇ ГЕНЕЗИ ПРОСОЦАЛЬНОСТІ ОСОБИСТОСТІ}

Стаття висвітлюе основи вікової динаміки гуманістично зорієнтованої стратегії особистості, механізми формування мотивачії на користь Іншого, витоки та передумови уважного ставлення до партнерів по взаємодії та їх розвиток у процесі соиіалізації. Обговорюються сутнісні характеристики психологічних механізмів просоиіальності особистості, їх трансформування та зміна особливостей функиіонування впродовж онтогенезу. Висвітлюються питання переструктурування та особливостей взаємодії психологічних механізмів емпатійних тенденцій особистості, ї̈ готовності надавати підтримку та допомогу Іншому.

Ключові слова: просоціальність, психологічні механізми, наслідування, соціальна периепція, інтеріоризачія, ідентифікація, рефлексія, емоційне перемикання, моральна рефлексія, емпатія, стереотипізація, ретроспекція, цілепокладання, смислотворення.

Статтья освещает основы возрастной динамики гуманистически ориентированной стратегии личности, механизмы формирования мотиваџии в пользу Другого, зарождаюшиеся в раннем детстве механизмы внимательного отношения $\kappa$ партнерам по взаимодействию $и$ их дальнейшее развитие в проиессе соииализаиии. Обсуждаются сущностные характеристики 
психологических механизмов просочиальности личности, их трансформирование и изменение особенностей функционирования на протяжении онтогенеза. Освещаются вопросы переструктурирования и особенностей взаимодействия механизмов эмпатических тенденций личности, ее готовности оказывать содействие и помощь Другому.

Ключевые слова: просоциальность, психологические механизмы, наследование, сочиальная периепиія, интериоризация,эмоциональное перемыкание, моральна рефлексия, эмпатия, стереотипизация, ретроспекиия, целепокладание, смыслообразование.

Постановка проблеми. Питання соціально-психологічних особливостей і закономірностей поведінки людини у великих і малих соціальних спільнотах належить до актуальних напрямків психологічних пошуків. Особливу значущість, у цьому контексті, має розкриття психологічних механізмів гуманістичної взаємодії - механізмів, що обумовлюють готовність людей до партнерства, взаємної підтримки і допомоги, чутливого ставлення до потреб Іншого та його станів. Як відомо, у сучасній психологічної літературі не існує однозначного підходу до визначення сутності психологічного механізму. Переважно його визначають через категорію «суб'єктивного опису» чи «суб' єктивного відображення» об'єктивних процесів, які забезпечують взаємодію людини 3 оточуючим середовищем».

Аналіз останніх досліджень і публікацій. Психологічні механізми соціальної поведінки особистості аналізуються у роботах В. Г. Агеєва, І.С. Булах [2], В.Г. Леонтьєва, В.В. Сталіна. Як наголошує І. О. Коверзнєва, психологічні механізми мають різне функціональне навантаження, різну сферу дії, але всі вони лежать в основі різноманітних видів та форм активності людини, тому встановлення характеру, принципів, умови їх дії $є$ виключно важливим для розуміння людської активності [6, с.77]. Для нашого дослідження особливу значущість мають дослідження механізмів просоціальної поведінки. Зокрема у роботах Л.П.Журавльової [3], В. М. Вартанян, І.М.Коган, Т. В. Коломієць， В. І. Кротенко， В.3. Лучків， О. А. Орищенко обговорюються динамічні аспекти зародження і вікового розгортання механізмів емпатії. У дослідженнях І. М. Багмет, Г.С.Беккер, Т. В. Гольцової, І. Г. Лаверичєва аналізуються процеси розвитку альтруїстичних тенденцій та милосердя (Л. В. Данілова, Л.В.Іваненко, Г.М.Свідерська). У роботах зарубіжних і вітчизняних психологів піднімаються питання механізмів допомагаючої поведінки (Андреєв П. В., С. Браунел, М. Кьостер, Д. Соммервіль, С. Слоун, М. Торренс, Ф. Уорнекен. Все ж, спираючись на результати теоретичного аналізу проблеми, можна стверджувати, що питання вікового генезу механізмів різних видів просоціальної поведінки особистості у психологічній літературі висвітлено недостатньо.

Мета нашого дослідження зорієнтована на простеження вікової генези мотивів про соціальності особистості впродовж онтогенезу.

Виклад основного матеріалу дослідження. Просоціальність особистості - складне, інтегративне утворення. Його розвиток пов'язаний $з$ дією системи психологічних механізмів, які зумовлюють формування основних новоутворень у диспозиційній системі та визначають зміни у функціонування конструкта впродовж онтогенезу. Не зупиняючись на описі кожного із механізмів (вони детально аналізуються при висвітленні явища соціалізації), позначимо їх вікову динаміку у процесі просоціального розвитку. До основних механізмів розвитку просоціальності ми відносимо: наслідування, перцепцію (з механізмом предметного та соціального спрямування), інтеріоризацію, ідентифікацію, рефлексію, емоційне перемикання, моральну рефлексію, емпатію, стереотипізацію, ретроспекцію, цілепокладання, смислотворення.

Механізм наслідування простежується у просоціальній поведінці людини впродовж усього життя, але найвагоміший вплив він має на початкових етапах онтогенезу (Л. Ф. Обухова, I. В. Шаповаленко, В. Просецький). Як засвідчують результати наукових спостережень, здатність до наслідування гуманістично-орієнтованої поведінки інтенсивно формується впродовж раннього дитинства (В. В. Абраменкова [1]). Воно виявляється у спрощеному відтворенні сприяючої поведінки дорослого, імітації його дій з можливим виникненням реакцій емпатійного відгуку чи без них. На нашу думку, наслідування, як механізм первинного набуття просоціального досвіду, починає функціонувати 3 початку другого року життя, що відповідає другому етапу його розвитку за класифікацією В. О. Просецького. На цьому етапі відбувається виокремлення окремих соціально орієнтованих дії дорослого і їх відтворення. Якісні перетворення у механізмі просоціального наслідування відбуваються на завершальному етапі раннього дитинства, з переходом на рівень, що дістав назву символічного моделювання (Л. П. Обухової, І.В.Шаповаленко). У дітей виникає здатність простежувати ланцюг просоціальних дій дорослого і відповідно наслідувати найпростіші форми поведінки. Подальші зміни відбуваються на етапі ігрового та узагальнено-символічного імітування завдяки переходу дітей до відтворення узагальнених схем просоціальної поведінки не 
окремої людини, а «соціального дорослого», що забезпечує інтеріоризацію норм співжиття, взаємодопомоги і підтримки. 3 цього етапу відбувається не лише трансформування імітаційних можливостей дитини, а й об'єднання механізму наслідування з більш пізніми способами когнітивної і емоційної орієнтації.

Не зупиняючись на механізмах генетичного зумовлення просоціальних форм реагування зазначимо, що у період раннього дитинства засвоєння основ просоціальності пов'язане також 3 функціонуванням механізмів периепиії та іiі особливого різновиду - соціальної перцепції (В. В. Абраменкова, О.В. Запорожець, В. С. Мухіна). Когнітивні операції першої групи дозволяють дитині виокремлювати зміни, що відбуваються у світі предметів. Це важливий елемент як декодування ситуацій 3 потенційним просоціальним контекстом, так і прийняття релевантних рішень щодо необхідності втручання в ситуацію. Механізми соиіальної периепції - це спосіб проникнення у ментальний світ іншої людини, простеження зв'язку між намірами, станами і діями людини. Вибудовуючись 3 перших днів життя механізм перцепції $\epsilon$ умовою i засобом формування просоціальних реагувань та розвитку просоціальності особистості.

Просоціальна поведінка - різновид соціальних програм людини, тому закономірно, що ії розвиток неможливий без механізму інтеріоризації. Впродовж багатовікової історії людство сформувало основні правила співжиття. Однією із ліній нормативної системи $є$ правила просоціальної групи. Механізм їх виокремлення та присвоєння започатковується 3 періоду дошкільного дитинства (О. М. Леонтьєв, Л. С. Виготський). На кожному з періодів онтогенезу механізм інтеріоризації виконує різні функції у формуванні просоціальності особистості. На початкових етапах - увага до соціальних і моральних норм, трансформація зовнішньої активності у внутрішні структури психіки веде до появи внутрішньої мислиннєвої діяльності, формування нового бачення системи «Я-інший», виникнення первинних особистісних норм просоціального змісту.

Здатність людини до емпатії у психологічній науці визнається і як різновид просоціальної самореалізації, і як один 3 механізмів формування особистісної якості (Т. П. Гаврилова, Т. Д. Карягіна, К. Роджерс). Механізм емоційного перемикання забезпечує не лише виникнення уваги до емоційних станів іншого, а й зміну емоційного самопочуття в емпатогенних ситуаціях (С. А. Белічева, Л. П. Журавльова [3]). Як наслідок виникає здатність до емоційної децентрації, розуміння станів іншого, виникнення співчуття та співпереживання. На кожному із періодів онтогенезу механізм емпатії обумовлює все нові і нові можливості просоціального реагування. Саме він, забезпечуючи розгортання антиципуючих емпатійних відносин, сприяє інтеграції процесів становлення емпатійності як особистісної якості у підлітковому та юнацькому періодах. У зрілому віці завдяки ускладненню моносуб'єктної трансфінітної емпатії здійснюється продуктивне піклування про інших на основі сформованих екзистенційних потреб, усталених процесів смислотворення, самореалізації через духовне та універсальне емпатійне ставлення.

Як і всі інші особистісні якості просоціальність особистості не може сформуватися за відсутності механізму ідентифікащиї - здатності виходити за межі Я, привносити у структуру свідомості особливості, схильності, почуттів інших та переживати їх як свої. Ідентифікація сприяє формуванню ставлення до себе як суб' єкта допомоги, появу конструкта «просоціальна ідентичність». Вона забезпечує психологічні основи для активної участі у вирішенні проблем іншого, засвоєння конвенційних норм, правил, ролей. Загальні особливості механізму ідентифікації детально проаналізовані у низці наукових робіт (В. С. Мухіна С. Л. Рубінштейн, О. М. Леонтьєв А. В. Мудрик). Вікова генеза механізму ідентифікації у лоні просоціальних цінностей забезпечує поступовий рух у напрямку побудови та реалізації ідеального просоціального Я образу.

У розвитку просоціальності особистості важливу функцію виконує механізм рефлексії. Його сутність і динаміка достатньо широко висвітлена у наукових джерелах. Вікові аспекти розвитку рефлексивних процесів в період молодшого шкільного віку, у лоні моральної проблематики, презентовано в роботах А. В. Мудрик, Р. В. Павелківа, Н. О. Яцюк. Становлення механізму особистісної та моральної рефлексії у процесах особистісного зростання в підлітковому віці розкрито у роботах I. С. Булах [2]. На нашу думку, ознаки просоціальної рефлексії, як різновиду означених процесів, можна спостерігати 3 періоду дошкільного дитинства. Саме процеси моральної та особистісної рефлексії забезпечують можливість аналізувати власну участь у життєдіяльності інших, оцінювати іiі як нормативну стратегію. Генеза механізмів рефлексії забезпечує виокремлення та подальше функціонування просоціальної ідентичності, побудову просоціальних поведінкових програм відповідно до системи гуманістичних цінностей і власних переконань.

На етапах дорослішання система механізмів просоціального розвитку особистості доповнюється процесами цілепокладання, смислотворення та стереотипізації. Зокрема механізм цілепокладання забезпечує людині здатність визначати особистісно значущі цілі щодо підтримки 
інших, вибудовувати модель просоціальної самореалізації. Його загальна сутність проаналізована у роботах В.Архипова, В. Г. Асєєва, Л. С. Виготського. Механізм смислотворення - основа зрілої психіки (К. Абульханова-Славська; В. О. Татенко [7], Т. М. Титаренко, В. М. Ямницький). Його виокремлення у руслі значущої для нас проблематики дозволяє простежувати розвиток просоціальної суб'єктності як внутрішньої здатності до самовизначень у ситуаціях з потенційним просоціальним контекстом.

Смислотворення забезпечує дорослій людині творчу, духовну просоціальну самореалізацію. У період пізньої дорослості цей механізм сприяє збереженню ціннісної сутності «Я» образу, подальшу просоціальну участь людини у житті інших, що $є$ важливою лінією програм позитивного старіння. У цей віковий період загальна система функціонування конструкта доповнюється механізмом peтроспекції. Аналіз його сутноті і функціонування здійснено плеядою вітчизняних психологів (I. С. Булах, В. О. Татенко). У контексті просоціального розвитку механізм ретроспекції сприяе актуалізації образу просоціального «Я», шляхом пригадування та аналізу власного просоціального досвіду, його використання для подальшого утвердження просоціальної самореалізації, персоніфікації поведінки. Процес ретроспекції разом 3 механізмом стереотипізації - основа збереження активних просоціальних позицій у період пізньої зрілості. таблиці 1.

Вікова динаміка психологічних механізмів розвитку просоціальності особистості подана у

Таблиия 1

Вікова генеза психологічних механізмів просоціальності особистості

\begin{tabular}{|c|c|c|}
\hline Основні механізми & $\begin{array}{l}\text { Змістова сутність механізму на } \\
\text { кожному з етапів розвитку } \\
\text { просоціальності особистості }\end{array}$ & Наслідки функціонування \\
\hline 1 & 2 & 3 \\
\hline \multicolumn{3}{|c|}{ Етап інтегративної просоціальності } \\
\hline $\begin{array}{l}\text { смислотворення } \\
\text { (К. Абульханова- } \\
\text { Славська; } \\
\text { В. О. Татенко } \\
\text { Т. М. Титаренко, } \\
\text { В. М. Ямницький ) }\end{array}$ & $\begin{array}{l}\text { функціонування просоціальної } \\
\text { суб’єктності як внутрішньої } \\
\text { готовності до самовизначення у } \\
\text { ситуаціях з потенційним } \\
\text { просоціальним контекстом }\end{array}$ & $\begin{array}{l}\text { творча, духовна просоціальна } \\
\text { самореалізація як лінія } \\
\text { позитивного старіння, } \\
\text { збереження ціннісної сутності } \\
\text { «Я» образу }\end{array}$ \\
\hline $\begin{array}{l}\text { ретроспекція } \\
\text { (І.С.Булах, } \\
\text { В. О. Татенко) }\end{array}$ & $\begin{array}{l}\text { актуалізація образу просоціального } \\
\text { «Я», пригадування та аналіз } \\
\text { власного просоціального досвіду }\end{array}$ & $\begin{array}{l}\text { використання минулого для } \\
\text { утвердження просоціальної } \\
\text { самореалізації, персоніфікація } \\
\text { поведінки }\end{array}$ \\
\hline $\begin{array}{l}\text { емпатія } \\
\text { (Л.П.Журавльова, } \\
\text { Т. П. Гаврилов, } \\
\text { Т. Д. Карягіна, } \\
\text { К. Роджерс) }\end{array}$ & $\begin{array}{l}\text { ускладнення моносуб'єктної } \\
\text { трансфінітної емпатії }\end{array}$ & $\begin{array}{l}\text { продуктивне піклування про } \\
\text { інших на основі сформованих } \\
\text { екзистенційних потреб, } \\
\text { усталених процесів } \\
\text { смислотворення, самореалізації } \\
\text { через духовне та універсальне } \\
\text { емпатійне ставлення }\end{array}$ \\
\hline \multicolumn{3}{|c|}{ Етап особистісно досягнутої просоціальності } \\
\hline $\begin{array}{l}\text { смислотворення } \\
\text { (К. Абульханова- } \\
\text { Славська; В. О. Татенко } \\
\text { Т. М. Титаренко, } \\
\text { В. М. Ямницький) }\end{array}$ & $\begin{array}{l}\text { розвиток просоціальної } \\
\text { суб’єктності як внутрішньої } \\
\text { здатності до самовизначення у } \\
\text { ситуаціях з потенційним } \\
\text { просоціальним контекстом }\end{array}$ & $\begin{array}{l}\text { творча, духовна просоціальна } \\
\text { самореалізація як лінія } \\
\text { перетворення себе та свого } \\
\text { життєвого середовища }\end{array}$ \\
\hline $\begin{array}{l}\text { ідентифікація } \\
\text { (В.С. Мухіна , } \\
\text { А.В. Мудрик } \\
\text { С.Л. Рубінштейн } \\
\text { О.М. Леонтьєв,) }\end{array}$ & $\begin{array}{l}\text { переживати свою присутність у } \\
\text { життєвому світі іншого як } \\
\text { особистісну стратегію }\end{array}$ & $\begin{array}{l}\text { орієнтація на світогляд у } \\
\text { побудові та реалізації ідеального } \\
\text { просоціального Я образу }\end{array}$ \\
\hline
\end{tabular}




\begin{tabular}{|c|c|c|}
\hline $\begin{array}{l}\text { емпатія } \\
\text { (Л. П. Журавльова, } \\
\text { Т. П. Гаврилов, } \\
\text { Т. Д. Карягіна, } \\
\text { К. Роджерс) }\end{array}$ & $\begin{array}{l}\text { ускладнення моносуб’єктної } \\
\text { трансфінітної емпатії }\end{array}$ & $\begin{array}{l}\text { продуктивне піклування про } \\
\text { інших на основі розвитку } \\
\text { екзистенційних потреб, } \\
\text { розгортання процесів } \\
\text { смислотворення, самореалізації } \\
\text { через духовне та універсальне } \\
\text { емпатійне ставлення }\end{array}$ \\
\hline $\begin{array}{l}\text { стереотипізація } \\
\text { (В. С. Асєєв, } \\
\text { Н. П. Суходольська) }\end{array}$ & $\begin{array}{l}\text { здатність до вироблення стійких, } \\
\text { еталонних схем реагування у } \\
\text { просоціальних ситуаціях, на основі } \\
\text { селекції, категорізації, оціночної } \\
\text { поляризації соціальної інформації }\end{array}$ & $\begin{array}{l}\text { прискорена, спрощена, } \\
\text { автоматизована побудова } \\
\text { просоціальних програм, вибір } \\
\text { адекватних реакції в } \\
\text { емпатогенних ситуаціях на } \\
\text { основі узагальнення } \\
\text { попереднього життєвого досвіду }\end{array}$ \\
\hline \multicolumn{3}{|c|}{ Етап позиційної просоціальності } \\
\hline $\begin{array}{l}\text { ідентифікація } \\
\text { (В. С. Мухіна, } \\
\text { А.В. Мудрик } \\
\text { С. Л. Рубінштейн, } \\
\text { О. М. Леонтьєв) } \\
\end{array}$ & $\begin{array}{l}\text { здатність поставити себе на місце } \\
\text { іншої людини, переживати свою } \\
\text { присутність у життєвому світі } \\
\text { іншого }\end{array}$ & $\begin{array}{l}\text { розвиток просоціальної } \\
\text { ідентичності }\end{array}$ \\
\hline $\begin{array}{l}\text { цілепокладання } \\
\text { (В. Архипов, В. Г. Асєєв, } \\
\text { Л. С. Виготський) }\end{array}$ & $\begin{array}{l}\text { здатність визначати особистісно } \\
\text { значущі цілі щодо підтримки інших }\end{array}$ & $\begin{array}{l}\text { побудова ідеальної моделі } \\
\text { просоціальної самореалізації }\end{array}$ \\
\hline $\begin{array}{l}\text { моральна рефлексія } \\
\text { (І. С. Булах, } \\
\text { Н. І.Гуткіна, } \\
\text { Р. В. Павелків) }\end{array}$ & $\begin{array}{l}\text { утвердження моральної автономії, } \\
\text { розгортання процесів метапізнання } \\
\text { у змістово-смисловому полі } \\
\text { нормативного просоціального «Я» }\end{array}$ & $\begin{array}{l}\text { функціонування просоціальної } \\
\text { ідентичності, побудова } \\
\text { просоціаль- } \\
\text { них поведінкових програм } \\
\text { відповід- } \\
\text { но до світоглядних цінностей }\end{array}$ \\
\hline $\begin{array}{l}\text { емпатія } \\
\text { (Л. П. Журавльова, } \\
\text { Т. П. Гаврилов, } \\
\text { Т. Д. Карягіна, } \\
\text { К. Роджерс) }\end{array}$ & $\begin{array}{l}\text { розгортання антиципуючих } \\
\text { емпатійних відносин, } \\
\text { трансцедентної емпатії }\end{array}$ & $\begin{array}{l}\text { інтеграція процесів у } \\
\text { становлення емпатійності як } \\
\text { особистісної якості }\end{array}$ \\
\hline $\begin{array}{l}\text { стереотипізація } \\
\text { (В. С. Асєєв, } \\
\text { Н. П. Суходольська) }\end{array}$ & $\begin{array}{l}\text { здатність до побудови еталонних } \\
\text { схем оцінювання і реагування у } \\
\text { просоціальних ситуаціях,на основі } \\
\text { селекції, категорізації, оціночної } \\
\text { поляризації соціальної інформації }\end{array}$ & $\begin{array}{l}\text { прискорення та автоматизація } \\
\text { прийняття просоціальних рішень } \\
\text { та вибору стратегії реагування }\end{array}$ \\
\hline $\begin{array}{l}\text { моральна рефлексія } \\
\text { (І. С. Булах, Н. І. Гуткіна, } \\
\text { Р. В. Павелків) }\end{array}$ & $\begin{array}{l}\text { прийняття просоціальних } \\
\text { цінностей на основі внутрішнього } \\
\text { діалогу; оцінювання себе і своєї } \\
\text { поведінки відповідно до соціальних } \\
\text { і моральних норм.осмислення } \\
\text { просоціального «Я» }\end{array}$ & $\begin{array}{l}\text { дотримання моральних приписів } \\
\text { у просоціальних ситуаціях; } \\
\text { переживання почуттів сорому і } \\
\text { провини при порушенні норм } \\
\text { моральна автономія }\end{array}$ \\
\hline \multicolumn{3}{|c|}{ Етап нормативно-диспозицйної просоціа ільності } \\
\hline $\begin{array}{l}\text { ідентифікація } \\
\text { (В.С. Мухіна } \\
\text { С.Л. Рубінштейн, } \\
\text { О. М. Леонтьєв } \\
\text { А. В. Мудрик) }\end{array}$ & $\begin{array}{l}\text { здатність поставити себе на місце } \\
\text { іншого; включення просоціальних } \\
\text { якостей до Я-образу }\end{array}$ & $\begin{array}{l}\text { формування ставлення до себе } \\
\text { як суб’єкта допомоги, поява } \\
\text { конструкта «просоціальна } \\
\text { ідентич- } \\
\text { ність»; активна участь у } \\
\text { вирішенні проблем іншого, } \\
\text { засвоєння конвенційних норм, } \\
\text { правил ролей, }\end{array}$ \\
\hline $\begin{array}{l}\text { емпатія } \\
\text { (Л. П. Журавльова, } \\
\text { Т. П. Гаврилов, }\end{array}$ & $\begin{array}{l}\text { поява моносуб’єктності та } \\
\text { групоцентричності у системі } \\
\text { емпатійних відносин }\end{array}$ & $\begin{array}{l}\text { розвиток емпатійності як } \\
\text { вікового новоутворення }\end{array}$ \\
\hline
\end{tabular}




\begin{tabular}{|c|c|c|}
\hline $\begin{array}{l}\text { Т. Д. Карягіна, } \\
\text { К. Роджерс) }\end{array}$ & & \\
\hline $\begin{array}{l}\text { інтеріоризація } \\
\text { (О. М. Леонтьев, } \\
\text { Л. С. Виготський) }\end{array}$ & $\begin{array}{l}\text { прийняття соціальних і моральних } \\
\text { норм на рівні ціннісної системи }\end{array}$ & $\begin{array}{l}\text { формування змістової } \\
\text { просоціальної ідентичності }\end{array}$ \\
\hline \multicolumn{3}{|c|}{ Етап соціально-нормативної просоціальності } \\
\hline $\begin{array}{l}\text { емоційне перемикання } \\
\text { (С. А. Белічева, } \\
\text { Л. П. Журавльова) }\end{array}$ & $\begin{array}{l}\text { увага до емоційних станів іншого, } \\
\text { зміна емоційного самопочуття в } \\
\text { емпатогенних ситуаціях }\end{array}$ & $\begin{array}{l}\text { розуміння емоційних } \\
\text { переживань іншого; виникнення } \\
\text { співчуття та розвиток } \\
\text { співпереживання }\end{array}$ \\
\hline $\begin{array}{l}\text { рефлексія } \\
\text { (А. В. Мудрик, } \\
\text { Р. В. Павелків } \\
\text { Н. О. Яцюк ) }\end{array}$ & $\begin{array}{l}\text { здатність думати про свою участь у } \\
\text { життєдіяльності іншого як } \\
\text { нормовідповідну стратегію }\end{array}$ & $\begin{array}{l}\text { первинне формування } \\
\text { суб’єктності у ситуаціях } \\
\text { просоціального типу }\end{array}$ \\
\hline $\begin{array}{l}\text { ідентифікація } \\
\text { (В. С. Мухіна } \\
\text { С. Л. Рубінштейн, } \\
\text { О. М. Леонтьєв } \\
\text { А. В. Мудрик) }\end{array}$ & $\begin{array}{l}\text { приписування собі особливостей, } \\
\text { схильностей, почуттів інших та } \\
\text { переживати їх як свої }\end{array}$ & $\begin{array}{l}\text { формування механізмів } \\
\text { соціальної поведінки, } \\
\text { становлення відносин з іншою } \\
\text { людиною на позитивних } \\
\text { емоційних засадах; побудова } \\
\text { позитивного «Я» образу }\end{array}$ \\
\hline $\begin{array}{l}\text { наслідування } \\
\text { (Л.Ф. Обухова, } \\
\text {. В. Мудрик } \\
\text { І. В. Шаповаленко, } \\
\text { В. Просецький) }\end{array}$ & $\begin{array}{l}\text { виокремлення поведінки } \\
\text { дорослого як соціального зразка в } \\
\text { емпатогенних та потенційно } \\
\text { просоціальних ситуаціях }\end{array}$ & $\begin{array}{l}\text { відтворення набору дій } \\
\text { відповідно до засвоєної схеми }\end{array}$ \\
\hline $\begin{array}{l}\text { інтеріоризація } \\
\text { (О.М.Леонтьев, } \\
\text { Л. С. Виготський } \\
\text { В. К. Вілюнас) }\end{array}$ & $\begin{array}{l}\text { увага до соціальних і моральних } \\
\text { норм, трансформація зовнішньої } \\
\text { активності у внутрішні структури } \\
\text { психіки; ставлення у системі «Я- } \\
\text { інший» }\end{array}$ & $\begin{array}{l}\text { поява внутрішньої мислительної } \\
\text { діяльності; виникнення } \\
\text { первинних особистісних норм }\end{array}$ \\
\hline \multicolumn{3}{|c|}{ Етап елементарної просоціальності } \\
\hline \multirow{2}{*}{$\begin{array}{l}\text { перцепція; } \\
\text { соціальна перцепція } \\
\text { (О. В. Запорожець } \\
\text { В. В. Абраменкова, } \\
\text { В. С. Мухіна ) }\end{array}$} & $\begin{array}{l}\text { виокремлення змін у предметному } \\
\text { світі }\end{array}$ & $\begin{array}{l}\text { встановлення зв’язків між } \\
\text { змінами у предметному світі і } \\
\text { намірами іншого }\end{array}$ \\
\hline & 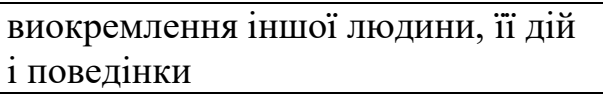 & $\begin{array}{l}\text { первинне розуміння намірів } \\
\text { іншого }\end{array}$ \\
\hline $\begin{array}{l}\text { наслідування } \\
\text { (Л.Ф. Обухова, } \\
\text { І. В. Шаповаленко, } \\
\text { В. Просецький) } \\
\end{array}$ & $\begin{array}{l}\text { спрощене відтворення дій } \\
\text { дорослого із можливим запуском } \\
\text { механізмів емоційного відгуку }\end{array}$ & $\begin{array}{l}\text { імітація дій дорослого } 3 \\
\text { елементами емоційного відгуку } \\
\text { чи без нього }\end{array}$ \\
\hline
\end{tabular}

Висновки та перспективи подальших досліджень. Психологічні механізми поведінки забезпечують організацію взаємодії людини з соціальним оточенням, реалізацію іï особистісних та міжособистісних програм. Це основа усіх різновидів соціальних зв'язків особистості з реальними і потенційними партнерами. Важливу роль у становленні особистості відіграє розвиток ії просоціальності - готовності і здатності діяти на благо іншої людини чи спільноти. Вікова динаміка просоціальної стратегії зумовлена онтогенетичними змінами у сфері психологічних механізмів соціальної поведінки, що виявляється у розширенні їх різновидів та зміні особливостей функціонування на кожному із вікових етапів. Подальший аналіз вікової специфіки просоціальності передбачає простеження особливостей поєднання різних психологічних механізмів соціальної поведінки у процесі соціалізації особистості.

\section{Список використаних джерел}

1. Абраменкова В. В. Социальная психология детства: Уч. пособ. / В. В Абраменкова. - Москва : ПЕР СЭ, 2008. - $431 \mathrm{c}$.

2. Булах І. С. Психологія особистісного зростання підлітків: реалії та перспективи / І. С. Булах. Вінниця : Нілан-лтд, 2016. - 340 с. 
3. Журавльова Л. П. Психологія емпатії: монографія. - Житомир: Вид-во ЖДУ ім. І Франка, 2007. $-328 \mathrm{c}$.

4. Гулевич О.А Индивидуальная помощь: когда и почему люди помогают друг другу? / О. А. Гулевич, Н. Ю. Амелина, О. В. Корсун // Психологические исследования нравственности. - Москва: Институт психологии РАН, 2013. - С. 71-97.

5. Лаверычева И.Г. Философские и естественнонаучные основания теории эгоизма и альтруизма: автореф. дис. ... канд. философ. наук: спец. 09.00.13 / И. Г. Лаверычева. - СанктПетербург, 2009. - 24 с.

6. Психология активности и поведения: учеб.-метод. комплекс / авт.-сост. И.А. Коверзнева.Минск: изд-во МИУ, 2010. - 316 с.

7. Татенко В. О. Методологія суб'єктно-вчинкового підходу: соціально-психологічний вимір: монографія / В.О. Татенко. - К. : Міленіум,2017.-184 с.

\section{References}

1. Abramenkova V. V. Sotsialnaya psihologiya detstva: Uch. posob. / V. V Abramenkova. - Moskva : PER SE, 2008. - $431 \mathrm{~s}$

2. Bulah I. S. PsihologIya osobistIsnogo zrostannya pIdlItkIv: realIYi ta perspektivi / I. S. Bulah. - VInnitsya : NIlan-ltd, 2016. - $340 \mathrm{~s}$.

3. Zhuravl`ova L. P. Psy’xologiya empatiyi: monografiya. - Zhy`tomy`r: Vy`d-vo ZhDU im. I Franka, 2007. - 328 s.

4. Gulevich O. A Individualnaya pomoshch: kogda i pochemu lyudi pomogayut drug drugu? / O. A. Gulevich. N. Yu. Amelina. O. V. Korsun // Psikhologicheskiye issledovaniya nravstvennosti. - Moskva: Institut psikhologii RAN. 2013. - S. 71-97.

5. Laverycheva I. G. Filosofskiye i estestvennonauchnyye osnovaniya teorii egoizma i altruizma: avtoref. dis. ... kand. filosof. nauk: spets. 09.00.13 / I. G. Laverycheva. - Sankt-Peterburg. 2009. $-24 \mathrm{~s}$.

6. Psikhologiya aktivnosti i povedeniya: ucheb.-metod. kompleks / avt.-sost. I.A. Koverzneva. - Minsk: izd-vo MIU. 2010. - 316 sNakonechna M. M. Dopomoga inshomu: psy`xologichny`j aspekt: monografiya / M. M. Nakonechna. - Ky`yiv : Vy`d. Dim «Slovo», 2012. $184 \mathrm{~s}$.

7. Tatenko V. O. MetodologIya sub'Ektno-vchinkovogo pIdhodu: sotsIalnopsihologIchniy vimIr: monografIya / V.O. Tatenko. - K. : MIlenIum, 2017. - $184 \mathrm{~s}$

\section{N. Korchakova PSYCHOLOGICAL MECHANISMS OF AGE-RELATED GENESIS OF PERSONALITY PROSOCIALITY}

The paper deals with the issue of the basic psychological mechanisms of genesis of prosociality as a unique personality trait, which manifests in actions associated with helping and supporting other people, taking into account their needs, intentions and emotional states. Prosociality is considered as a biosociopsychic construct which consists of the inner core components and peripheral one. Inner core combines prosocial identity, cognitive, emotional and motivational components. The peripheral part is represented by a behavioral component, which serves as an indicator of the evolution of this personality trait. The author considers the age-related genesis of prosociality as a lifetime evolution of the personal trait, expressed in a large diversity of developmental changes (separation and harmonization of the principal components; changes in its hierarchical structure and the transformation of dominant components) due to the shifts of the determinants and mechanisms that cause the varying levels and the features of prosocial activity.

Author discusses the main psychological mechanisms underlying the age-related changes in prosocial behaviors in different periods of ontogeny such as emulation, object-oriented/ social perception, interiorization, identification, self-reflection, emotional switching, moral self-reflection, empathy, stereotypization, retrospection, goal setting and conceptualization. On the each stage of ontogeny underlying mechanisms determine increasing attention to the need of Others, occurrence of new or more complex forms of prosocial activity.

Presented information might clarify educational ways of stimulation of prosocial development during different periods of ontogeny. 
Key words: prosociality, prosocial behavior, psychological mechanisms, emulation, object-oriented/ social perception, interiorization, identification, self-reflection, emotional switching, moral self-reflection, empathy, stereotypization, retrospection, goal setting and conceptualization.

УДК 159.922.7-053.6:[159.9.07:37.04]

М. О. КОЦЬ, Т. М. ЯТЧУК

DOI: https://doi.org/10.35619/prap rv.vi12.59

\section{СПЕЦИФІКА ДІАГНОСТИКИ ОСОБИСТІСНОЇ СФЕРИ ПІДЛІТКІВ З ОСОБЛИВИМИ ОСВІТНІМИ ПОТРЕБАМИ}

У статті проаналізовано особливості діагностики особистісної сфери підлітків, що мають особливі освітні потреби. Визначено основні напрямки корекиійної роботи. Доведено, що в учнів, які мають порушення в особистісній сфері, наявні проблеми у контролі власних дій та емоційних реакцій. Також присутні тривалі негативні переживання, пригнічений настрій та недостатня розвиненість вольових зусиль та наявні тривожні стани.

Визначені за результатами діагностики особливості особистісної сфери підлітків з особливими освітніми потребами створюють підтрунтя для розроблення програми корекиійних занять з метою розвитку вольових зусиль та зняття тривожних станів.

Ключові слова: особистісна сфера, підлітковий вік, особливі освітні потреби, діагностика, корекиійна робота.

В статье проанализированы особенности диагностики личностной сферы подростков, имеютих особые образовательные потребности. Определены основные направления коррекционной работы. Доказано, что у учащихся, которые имеют нарушения в личностной сфере, существующие проблемы в контроле собственных действий и эмоциональных реакций. Также присутствуют длительные негативные переживания, подавленное настроение и недостаточная развитость волевых усилий и имеющиеся тревожные состояния.

Определень по результатам диагностики особенности личностной сферы подростков с особыми образовательными потребностями создают основу для разработки программы коррекиионных занятий с целью развития волевых усилий и снятия тревожных состояний.

Ключевые слова: личностная сфера, подростковый возраст, особые образовательные потребности, диагностика, коррекиионная работа.

Постановка проблеми. В сучасних економічних та суспільно-політичних умовах дедалі більше зростає частка осіб, в яких діагностуються порушення особистісної сфери. Складні геополітичні умови значно впливають на емоційну сферу людини, стають причиною затяжних депресивних станів, домінування бурхливих негативних емоційних реакцій, розвитку тривожних та фобічних станів. Таким впливам піддаються не тільки дорослі, а й підлітки, які прагнуть вивчати різноманітну інформацію з засобів масової інформації щодо ситуації в своїй державі та світі, перебудовують відносини з оточенням та прагнуть отримати бажану самостійність. Низки невдач в цих прагненнях можуть спричинювати серйозні порушення особистісної сфери та викривлені сприйняття реальності. На сьогодні досить важливим $є$ вивчення детермінантів порушення особистісної сфери у підлітковому віці, з метою психопрофілактики та психокорекції можливих ускладнень.

Аналіз останніх досліджень і публікацій. Відомо, що підлітковий вік є одним із ключових періодів у життєвому циклі людини та пов'язується з відповідною системою завдань, можливостей, переваг, а також небезпек, криз, збитків. У науковій літературі він постає як третьою фундаментальною ерою у життєвому шляху особистості, для якої притаманні зміни у царині психе, сома і поліс. Підлітковий вік тісно пов'язується з трьома основними соціально-культурними світами: сім'єю, школою та групою однолітків [2]. Саме ці основні сфери взаємодії тісно пов'язані 3 подальшим розвитком особистісної сфери. Значну частку часу підлітки проводять в стінах навчального закладу, в якому розвиваються емоційна та вольова сфери підлітка під впливом референтних осіб, до яких відносимо однокласників, друзів та вчителів. Несприятливі умови виступають чинниками, які призводять до виникнення порушень в структурі емоційно-вольової сфери: невмінні контролювати власні емоційні реакції та дії, надмірній тривожності, затяжних негативних емоційних станах та переживаннях.

Вивчення психологічних засобів оптимізації поведінкових стратегій особистості постійно перебувало у полі зору дослідників $[1 ; 2 ; 3 ; 4 ; 5 ; 6$ та ін.]. Так, Є. Калюжна, досліджуючи у своєму дисертаційному дослідженні психологічні механізми особистісної тривожності у підлітковому віці, Випуск 12, 2019. Збірник наукових праць РДГУ 